\title{
The Role of Environmental Factors in the Re-Breeding Of Waterfowl in the Steppe Zone
}

\author{
Turaev Mukhtor Murodovich, Kholliyev Askar Ergashovich
}

\begin{abstract}
The following article deals with ecological dis turbances in the Aral Sea, the rearrangement of the night herons' direction (Nysticorax nycticorax nysticorax $L$ ) to the south-east of the country, new information is provided about their entry into the Khorezm and Bukhara regions, their biotopic to ecological factors.
\end{abstract}

Key words: anthropogenic, biotope, biocenosis, population, regional, synanthropic, nominal, migrant, typical.

\section{INTRODUCTION.}

In natural biotopes, every change that is formed due to human economic activity is first and foremost provoked by representatives of the animal world in the territory, and each species reacts to the changes that occur, depending on the importance of this factor in its life, in the corresponding manifestations. If these changes lead to a reduction in the number of food sources of the species, then in such cases the species receives these changes in the form of "serious" discomfort and is observed to leave the territory in the short term. If these changes lead to the fact that the tour limits the possibilities of the places of stay, rest, construction of nests, then the tour can gradually leave the territory.

The Aral Sea and Aral Sea waters, which are considered the largest water basin of the Republic, and the archipelago, the archipelago, have for many years been chosen as the favorite habitat of representatives of the animal world, including water and underwater birds whose life is connected with water biotope. But by the second half of the last century, the unfavorable environmental situation on the territory began to have a negative impact on the life of a number of representatives of the animal world, including water and predatory bird species. As a result, many species in the reservoir for a short time left the territory.

Based on our many years of observations below and the information available in the literature, we can see that one of the typical representatives of the area (Nycticorax nycticorax n.the 1 . we have found it necessary to dwell on the changes occurring in the ecology of distribution, number, characteristics and behavior).

According to literature, the only population of 12-15 thousand pairs of Nycticorax nycticorax in Central Asia consists and representatives of this population, apparently corresponding to the ecological status of the territory, changes their territory with "migration" to regions with favorable opportunities (Mitropolsky, 2007).

Revised Version Manuscript Received on 16 September, 2019.

* Correspondence Author

Turaev Mukhtor Murodovich, PhD (Biology) Bukhara State University, Bukhara, Uzbekistan

Kholliyev Askar Ergashovich, DSc (Biology) Bukhara State University, Bukhara, Uzbekistan

\section{MATERIALS METHODOLOGY.}

These data were collected in Newiarik, Khiva, Bagat, Koshkopir districts of Khorezm region during 199997 and Olot, Karakul, Jondor, Kogon, Bukhara, Romitan districts and Bukhara cities of Bukhara region during 2000-2019 years.

Data on biology, number and distribution of Nycticorax nycticorax, composition of foods were analyzed on the basis of the methods of Kashkarov, 1927, Novikov, 1953, Koli,1979.

\section{DESCRIPTION OF THE MATERIAL.}

In the world fauna of the Nycticorax nycticorax there are 4 species, of which Nycticorax nycticorax L. the type is a nominal type, distributed throughout the territory of Uzbekistan. In the literature, a number of data on the ecology of the spread of this bird on the territory of Uzbekistan were given (Kostin, 1956, Spangenberg, 1957, Kenjegulov, 1967,Abdreimov, 1981,Sagitov, 1987, Shernazarov, 1992, Shernazarov, Turaev, 1994, Turaev, 1995, Mitropolsky, 2007, Torraev, 2008, Bakoev, Rahmonov, 2010).

The analysis of this data shows that the prevalence of the haqqush is closely related to the ecological situation of the territory. Until 1930 - 1950, among the representatives of all water and underwater bird species, the main distribution center of the Nycticorax nycticorax was the island sea and its tributaries (Butlerov, 1879, Zarudniy, Bilkevich, 1918, Salikhbaev, 1950, Kostin, 1956, Kenjegulov, 1967, Abdreimov, 1981.).

Since 1950, with the decrease in the water level of the sea water in the territory, the tendency of reduction in the number of the Nycticorax nycticorax was observed as a result of environmental changes in the Aral Sea and Aral Sea waters, especially in the Amudarya Delta and in the river banks, and at the same time representatives of this population began to observe the Sagitov, 1989, Shernazarov, 1994, Torraev, 1995, Torraev, 2008). Chunanchi, until the third quarter of the last century (1960-1970), in the central and south-eastern regions of the Republic is recorded low-number migrant species (Maslov 1947, Kostin, 1956, Salikhbaev, Ostapenko, 1967, Zohidov 1971).

The A.Kostin (1956), during his observations in Khorezm region, it was reported that the region recorded the meeting of haqqush in Korp, Shikh, Kurvanak lakes in small numbers in nutrition and that the species was in the construction of nests in the trees in the Kungrad District of Karakalpakstan. 
Since the 1970s, it has been observed that the Aral Sea population of the species has entered the territory of the Khorezm region of the Republic, and at the same time the number of Rights has increased compared to the 1960s. In particular, the fact that in 1967-1973 the Nycticorax nycticorax were recorded in the uya colonies, consisting of 340 large hubs, Baday-Tagay and Nurmanbobo (Left Bank of Amudarya) (Abduraimov, 1981). In 1999-1995 years, we recorded more than 300 colonies of hubs in Bagat, Khiva, Yangiarik, Koshkopir districts of the region (Ta'raev, 1995).

In the literature, as well as in the Nycticorax nycticorax 1950 years, the Bukhara region is interpreted as one of the few, autumn migrant species in the ponds (Maslov 1947). Data on the occurrence of Nycticorax nycticorax in the basins of water in the Karshi desert were not even cited (Salikhbaev, Ostapenko, 1967).

Since 1965-1970 years, from the account of the expansion of irrigated agricultural crop fields in the regions from the account of the increase in the level of groundwater in the regions, a number of artificial reservoirs - abandoned lakes, reservoirs and Fisheries were formed. These artificial reservoirs for water and underwater bird species, including Nycticorax nycticorax, which left the area due to the unfavorable ecological crisis in the waters of the island and the Aral Sea, have been mastered as a convenient shelter for a short time.

Since the 1970s, it has also been noted in Bukhara and Karshi desert waterfalls, as noted in the Ilgar Khorezm region, there has been an increasing number of Nycticorax nycticorax. In particular, in 1987, in the Karakir Lake of the region, a colony consisting of 400 hubs of the Nycticorax nycticorax was registered ( R.Sagitov and others.), The fact that during the 199-1991 years 50 pairs of Nycticorax nycticorax marries were recorded in the area of Alan and Achykul in the Sandikli desert (Shernazarov, 1992), is evidence of our opinion.

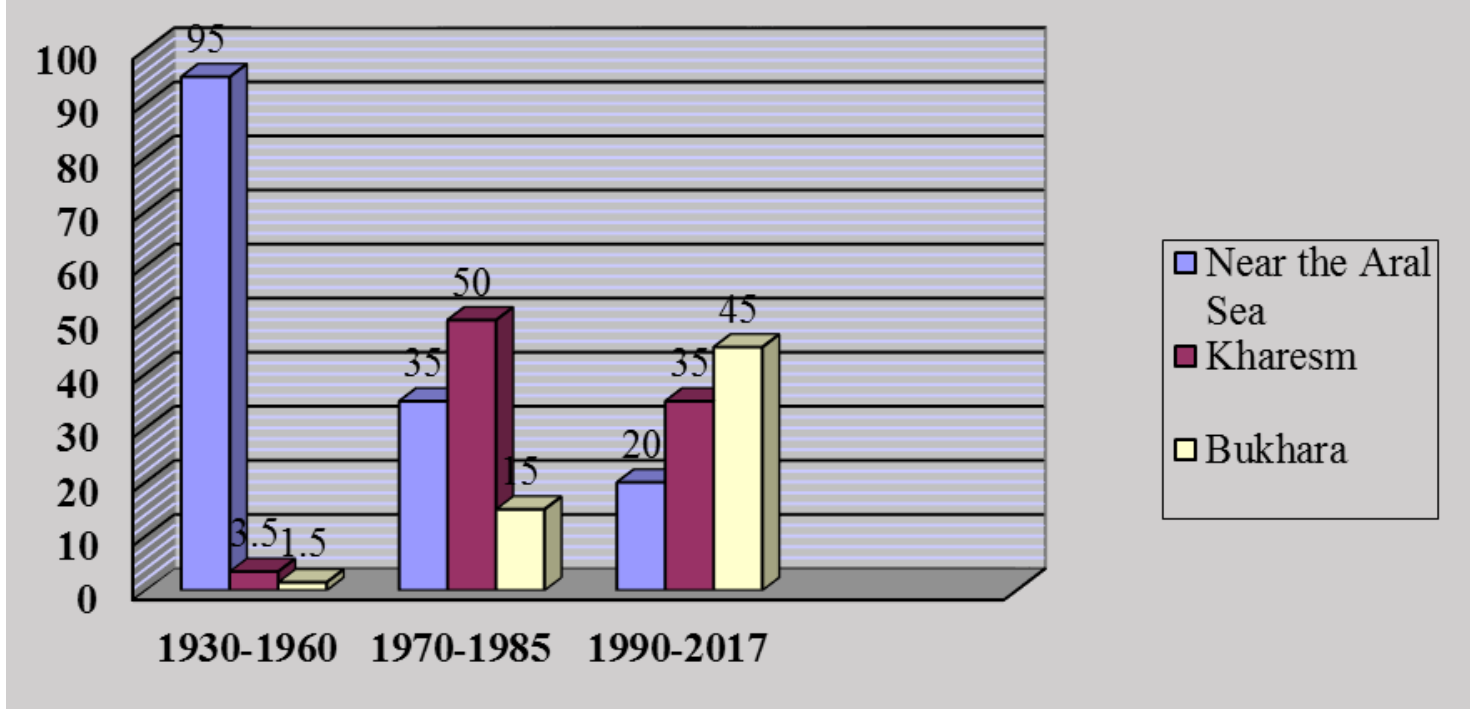

Nycticorax nycticorax's spread of the island population throughout the Republic (expression in \%)

It is known to us that the Nycticorax nycticorax community is a nest builder active bird, and in this connection they rest in the big woodpeckers, Taiga, reeds in the daytime and in the early morning they fly to their shallows for feeding close to the evening and are actively fed until the morning.

During migration, Nycticorax nycticorax is observed not only in the bare sections of woodlands, but also sometimes in the water and underwater bird species galas (Turaev, 1995.

Rights the colonies of nests are formed in natural conditions, usually in the lakes and fish farms, reeds and Taiga, in the rivers of the ponds a little calm and comfortable to feed. Slots in thick reed ponds are placed in the stacks of
Reed bushes (R.Sagitov and others. 1989, Ta'raev, 1995, 2008 ,). Sometimes in the case of limited opportunities for the construction of nests in ponds - in biotopes where, anthropogen activities are not strong, cases of the formation of nests colonies at a distance of $1.5 \mathrm{~km}$ to $5-8 \mathrm{~km}$ from the sources of nutrition are noted (Mitropolsky, 2007).

However, the main part of the colonies (close to $66 \%$ ) recorded in the conditions of Khorezm and Bukhara region, which we have observed, is observed on the banks of bus stops, which are busiest in the cities, districts and population punk centers with the highest population activity at distances from $1 \mathrm{~km}$ to $-12 \mathrm{~km}$ from water basins, in parks in the city table).

\section{Rights inns recorded in Bukhara region}

(Table-1)

\begin{tabular}{|c|c|c|c|c|c|c|}
\hline $\mathrm{T} / \mathrm{p}$ & $\begin{array}{l}\text { Places recorded } \\
\text { rights inns }\end{array}$ & $\begin{array}{l}\text { Num } \\
\text { ber }\end{array}$ & Recorded biotope & $\begin{array}{l}\text { Distance from food } \\
\text { profit place }\end{array}$ & $\begin{array}{l}\text { The main food } \\
\text { profit of inn }\end{array}$ & $\begin{array}{l}\text { Recorded } \\
\text { year of inns }\end{array}$ \\
\hline 1 & Olot district & 512 & The trees of Park & $\begin{array}{l}\text { From } 1-1,5 \text { to } \\
10-12 \mathrm{~km}\end{array}$ & $\begin{array}{l}\text { Dengizkul,Zovirku } \\
1,\end{array}$ & $\begin{array}{l}\text { 2000-2019 } \\
\text { Turaev }\end{array}$ \\
\hline 2 & $\begin{array}{l}\text { The centre of Karakul } \\
\text { district }\end{array}$ & 260 & The trees of Park & $\begin{array}{l}\text { From } 0,1-1,5 \\
10-12 \mathrm{~km}\end{array}$ & $\begin{array}{l}\text { Zarafshan River, } \\
\text { ditches, Zamonbobo } \\
\text { lake, }\end{array}$ & $\begin{array}{l}\text { 2004-2019 } \\
\text { Turaev } \\
\text { nd Engin }\end{array}$ \\
\hline
\end{tabular}




\begin{tabular}{|c|c|c|c|c|c|c|}
\hline 3 & Jondor district & 32 & $\begin{array}{l}\text { Near the Zarafshan } \\
\text { River }\end{array}$ & $0,1-0,5 \mathrm{~km}$ & $\begin{array}{l}\text { Zarafshan River, } \\
\text { ditches }\end{array}$ & $\begin{array}{l}\text { 2008-019 } \\
\text { Turaev }\end{array}$ \\
\hline 4 & Kagan district & 67 & The trees of Park & $2-9 \mathrm{~km}$ & ditches & $\begin{array}{l}\text { 2009-2019 } \\
\text { Тўраев }\end{array}$ \\
\hline 5 & Bukhara city & 320 & $\begin{array}{l}\text { The park of greening, } \\
\text { The trees of Park }\end{array}$ & $1-9 \mathrm{~km}$ & $\begin{array}{l}\text { ditches, Bukhara } \\
\text { fishing pools }\end{array}$ & $\begin{array}{l}\text { 2004-2019 } \\
\text { Turaev }\end{array}$ \\
\hline 6 & $\begin{array}{l}\text { Mokhi-Khossa } \\
\text { Mausoleum }\end{array}$ & 34 & The trees of Park & $2-8,5$ км & $\begin{array}{l}\text { ditches, Bukhara } \\
\text { fishing pools }\end{array}$ & $\begin{array}{l}\text { 2017-2019 } \\
\text { Turaev }\end{array}$ \\
\hline 7 & $\begin{array}{l}\text { The centre of } \\
\text { Rometan district }\end{array}$ & 282 & The trees of Park & $\begin{array}{l}\text { From } 0,1-0,5 \text { to } 1-9 \\
\mathrm{~km}\end{array}$ & $\begin{array}{l}\text { Zarafshan River, } \\
\text { Bukhara fishing pools }\end{array}$ & $\begin{array}{l}\text { 2004-2019 } \\
\text { Turaev }\end{array}$ \\
\hline 8 & $\begin{array}{l}\text { Rometan district } \\
\text { "Bogi Turkon" park }\end{array}$ & 56 & The trees of Park & $1-8 \mathrm{~km}$ & \begin{tabular}{|l|} 
ditches, Bukhara \\
fishing pools
\end{tabular} & $\begin{array}{l}\text { 2005-2019 } \\
\text { Turaev }\end{array}$ \\
\hline 9 & $\begin{array}{l}\text { Near the Zarafshan } \\
\text { River }\end{array}$ & 32 & Reed & $0,1-0,5 \mathrm{~km}$ & Zarafshan River & $\begin{array}{l}\text { 2002й, } \\
\text { Тўраев }\end{array}$ \\
\hline 10 & Karakyr Lake & 400 & Reed & - & Karakyr Lake & $\begin{array}{l}1988, \\
\text { R.Sagitov, } \\
2017, \\
\text { Turaev }\end{array}$ \\
\hline 11 & Zamonbobo Lake & 120 & Reed & - & Zamonbobo Lake & $\begin{array}{l}\text { 2004-2017 } \\
\text { Turaev }\end{array}$ \\
\hline & Total & 2115 & & & & \\
\hline & In cities & 1055 & In trees & \multicolumn{3}{|l|}{$65,6 \%$} \\
\hline & In lakes & 552 & In reeds & \multicolumn{3}{|l|}{$34,4 \%$} \\
\hline
\end{tabular}

Beginning from the first ten days of April, the efforts of the Nycticorax nycticorax to build nests in Uzbekistan,the observation of the opening of full chickens in the first ten days of May (06.05) is recorded in the literature (Sagitov, 1987). In the conditions of Bukhara region, too, basically this term is suitable. But some note that in the years when the winter has come warm, in the early spring, these actions (depending on the weather temperature) can begin from the first ten days of March (9.03.08) (Ta'raev, 2008).

Even in all of the observed colonies, the opening of the chick shows a different appearance in the colonies, since these movements are headed at the same time. The earliest attempts to lay eggs and open the chicks were observed in the colony in the park in the Romitan district and these deadlines are in the appropriate order 09.03.08., 19.03.19 was recorded. 28.04 .08 . on the day when the colony was examined, in $77,2 \%$ of the nests in it, chicks were opened, and the remaining $22,8 \%$ of the nests were recorded eggs pressed to a different level. And in the colonies in Bukhara, the first chick was 22.04.08, 17.04.19.was recorded at.

We have witnessed that all the recorded nests were composed of mixed colonies consisting of small white crows (Egretta garzetta) and Egyptian Crows (Bubulcus ibis ibis) from representatives of the family of crows (Corvus frugilegus), sometimes in this composition. Slots were placed on Maple, Elm, moth and mulberry trees.

Similar actions were observed in the Khorezm region around gardens, cemeteries and ponds under the influence of anthropogen activity of $90 \%$ of the nests recorded in Bagat, Yangiarik, Khiva, Kushkupir districts. These nests, however, are composed of colonies with pure content, and are located on the trees of the elderberry and Sada Birch.
Since the nests are placed on the basis of branches, branches and branches in the branched part of the trees, the height of the nests from the ground varies from 5 -14 $\mathrm{m}$.sometimes from $17-22 \mathrm{~m}$. varies up to. The period of laying eggs of birds begins from the middle of March, April, and lasts until May, depending on the weather, as if it was autumn in all species. But the results of our observations show that these actions are related to the location of the colony's composition and its condition, that is, if the colony is placed on trees, it will allow it to start slightly earlier than the nest colonies in the reeds.

In particular, in the Romitan Park, in the woodlands of the Romitan Central Hospital, in the parks of the alot and Karakol districts, the choice of bird flying and nesting places began from the last days of February $(26.02 .08,24.02 .19)$, from the first ten days of March $(9.03 .08 ; 19.03 .19$.) it was noted that the first eggs were laid in the nests. This term differs slightly from the term for the construction of nests in lakes and the duration of reproduction.

The main factor in this is primarily the high humidity in the reeds in the reservoirs, while in the tree biotopes in the cities the weather is relatively moderate.

Also in urban conditions, the formation of the right-wing colonies on trees is of particular importance, sometimes it is observed that the nests can be reused in the coming years. In particular, in 2008, 17 of the 231 Nycticorax nycticorax nests recorded in the Central Park of Romitan district witnessed the use of last year's nests of Nycticorax nycticorax, while 34 of the abandoned nests of last year's Nycticorax nycticorax were used in the same situation, 12 of the 78 nests recorded respectively in the tree beds of the District Central Hospital and 


\section{The Role of Environmental Factors in the Re-Breeding Of Waterfowl in the Steppe Zone}

Diagram-2

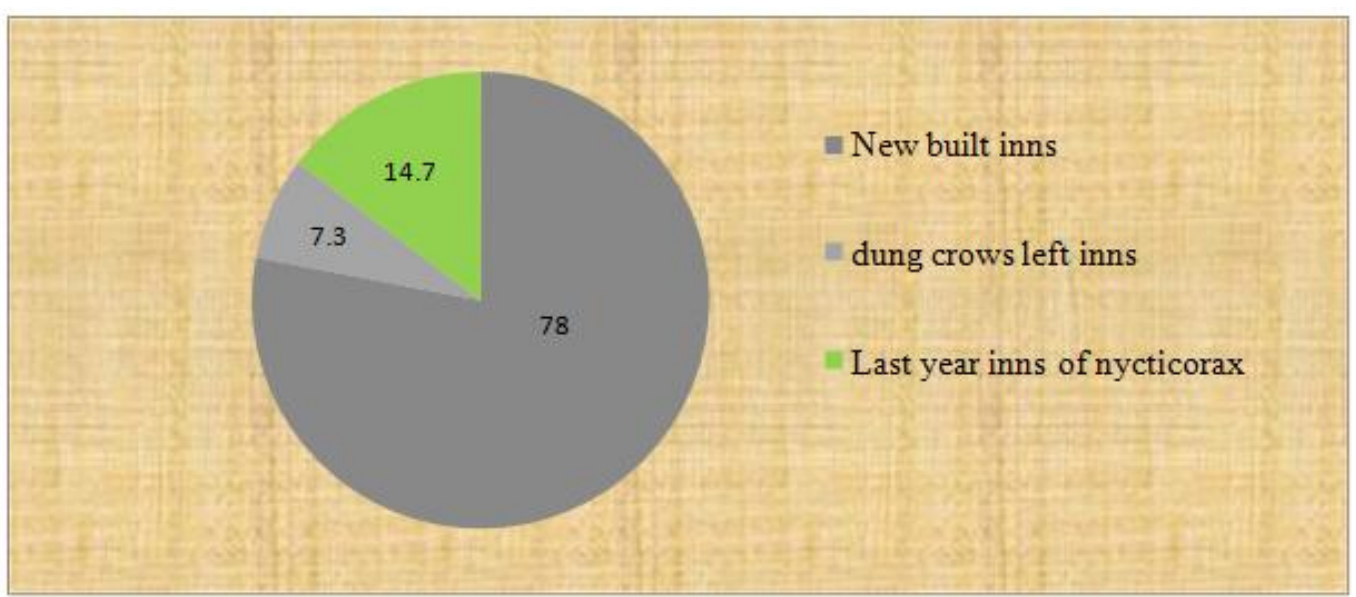

Nycticorax nycticorax nests recorded in Romitan amusement park (analysis in \%)

The delay in laying eggs in the reeds in the Lakes is due to the fact that the birds change the place of building nests every year and each time they lose some time to choose the place of nests. (1-diagram).

The movement of laying eggs in the colony of the haqqushs, recorded in the region's Lake Karakir, begins from the last days of April (25.04.87) and continues until the first half of May (R.Sagitov, 1989, Shernazarov, 1992, Torraev, 2008

This is due to the fact that the number of eggs laid in the nests varies depending on the length of the nest from the place of feeding. In the nests of Lake karakir $(n=70)$, we witnessed that the average 3,0 eggs were correct, in the colony of Romitan $(n=24)$, on average 2,7 . In this way, the role of the hive in relation to the sources of nutrition determines the number of eggs in the nest and the chances of feeding the bird chicks. In particular: the nearest and main feeding place for each of the ikala colonies in the center of Romitan district is the Zarafshon river flowing through the territory of this district and this distance is $100-500 \mathrm{~m}$. In the Centers of alot, Karakol, Kagan districts, such a distance is from 1-2 km to $10-12 \mathrm{~km}$ Gach.

From the results of our observations, we were informed that the nutritional composition of the haqqush varies mainly in the number of species diversity in the corresponding watershed, with the formation of vertebrates and invertebrates flying in the reservoirs and its tributaries(3-diagram).

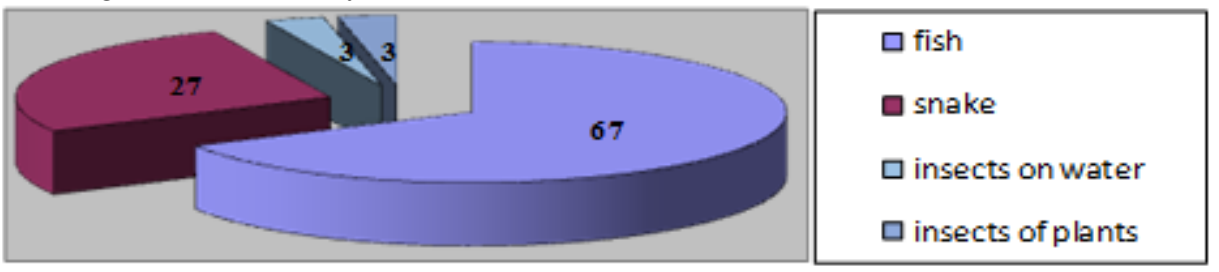

Food composition in the colony on the lakes in the Khorezm region

In particular, in the colony of Lake Hujakulgan of Khorezm region, the nutritional content of the haqqush was $67 \%$ of fish, $27 \%$ of water snake and $3 \%$ of water insects and $3 \%$ of dry insects (Ta'raev, 1995).

In the colony in the park of Romitan District of Bukhara region, $38 \%$ of this content is found in various fish, $15 \%$ in the water snake, $27 \%$ in the lake larva, $7 \%$ in the larvae and rodents, $12 \%$ in the land and water invertebrates crustaceans, water beetles, leeches, dragonflies, calves, dragonflies, calves, hardwoods and other dry insects(4Diagram).

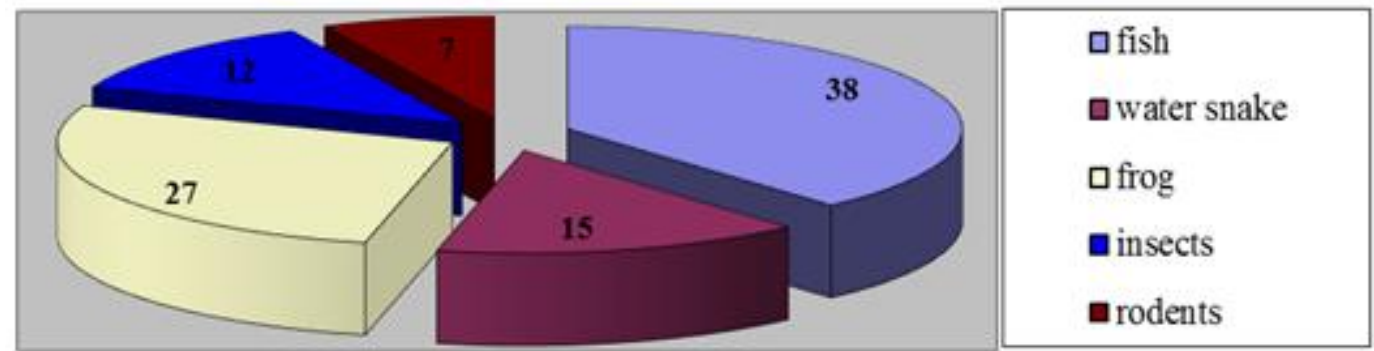

Food composition of Nycticorax nycticorax in Bukhara region in urban conditions

But the entropy undermines the integrity of the colonies under the influence of some manifestations of activity, including: in 2012-2013, the largest nest colony of the Nycticorax nycticorax in the city was completely destroyed due to the crossing of the tree of the regional greenery near the "Avtoshbekat" in Bukhara, and the birds spread to several new colonies when building nests. Or, as a result of the construction and tree cutting carried out in the amusement park "friendship" in the Olot District of the region in 2018 year, we witnessed that the number of slots in this colony in the district amounted to 44 thousand. In a similar situation, the implementation of tree cutting activities in romitan, Jondor, Karakul District Parks of the

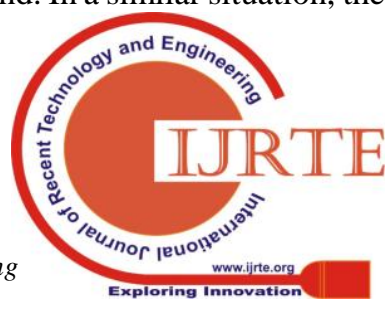


region leads to a change in the chances of Hukus to build nests.

\section{CONCLUSION}

In conclusion, due to the unfavorable environmental conditions in the Aral Sea region, the spread of the Nycticorax nycticorax in the Republic continues along the south-east direction of the lower-Amudarya area, since 1950, their number has been decreasing in the Aral Sea waters and at the same time the Republic is growing in Khorezm and especially in the territory of Bukhara region. It is also observed that in addition to creating colonies with some sinanthropic species on the territory of Nycticorax nycticorax Bukhara region, skills for anthropic activities (adaptation to strong interference in urban conditions, nutrition in artificial pools) are being strengthened. The sensitivity of the Nycticorax nycticorax to the opening of the nest was observed to fluctuate depending on the possibility of mastering the food, as well as the duration of the construction of the nest to be the basis of the early onset of the nest relative to the reeds in natural lakes, in cities depending on the location of the nest.

\section{REFRENCES}

1. Abdreimov T. Birds of tugai and adjacent deserts of the lower reaches of the Amu Darya // Tashkent, Ed. "FAN", 1981 p.109.

2. Bakhtishodovich, B. S., Khamidov, O., Mamayunusovich, P. O., Ramos-Ramos, S. E. R. G. I. O., Bobirshoyevich, M. S., \& Mukhamadaminovich, B. N. (2015). The Role Of Social Media, User Generated Platforms And Crowd Sourcing In The Development Of Tourism Destinations. Journal Of Hospitality Management And Tourism, 6(4), 30-38.

3. Kenzhegulov K. Ecology and significance of fish-eating birds in the lower reaches of the Amu Darya and the south of the Aral Sea: Abstract. Diss. Ph.D. - Tashkent, 1966. - 20 p.

4. Kashkarov D.N. A method for the quantitative study of vertebrate fauna and analysis of the obtained data // Transactions of SAGU. Series VIII-a, zoology, issue 1., Tashkent, 1927, 24 pp.

5. Koli, G. Analysis of Vertebrate Populations // Izd. M Mir, Moscow, 1979, 362 pp.

6. Lukashevich R.V. Some rare species of ankles of the Amu Darya delta and issues of their protection // Rare and poorly studied birds of Central Asia. Tashkent, 1990, pp. 54-57.

7. Mitropolsky O.V. Heron // Birds of Central Asia. T.1.-Almaty, 2007.S. 81-87.

8. Novikov G.A. Field research methodology for the ecology of terrestrial vertebrates. Moscow, 1953. C 7-591.

9. Bobur, S., \& Mashkhura, A. (2019). Economic essence and organizational features of free tourist zones. The case of Uzbekistan. International Journal on Economics, Finance and Sustainable Development, 1(1), 1-6.

10. Sagitov A.K. Ciconiiformes. // Birds of Uzbekistan. T.1. - Tashkent, 1987.S. 17-54.

11. Sagitov R.A., Pukinsky Yu.B., Pukinskaya M.V. Modern settlements of copepods and ankle birds on the lakes of Karakir, Bukhara region. II Fauna and ecology of birds in Uzbekistan. -Samarkand, 1989. S.193-205.

12. Spangenberg E.P. Ankle // Birds of the Soviet Union. T.2. - Moscow, 1951.P.446-453.

13. Eldarovna, G. N., Ochilov, K., \& Sobirov, B. (2019). Problems of transplantation of human organs and tissues: international standards and international experience. Religación. Revista de Ciencias Sociales y Humanidades, 4(16), 714-719.

14. Pardayev, O., \& Sobirov, B. (2015). THE WAYS OF IMPROVING THE PRODUCTIVITY OF "FROM GARDEN TO TABLEMATE" THROUGH DIFFUSING SYNERGETIC ADVANTAGES. Journal of Management Value and Ethics, 5(2).

15. Turaev M.M. Fauna population and ecology of birds in the lower reaches of the Amu Darya \ Avtoref. Diss. Ph.D. - Tashkent, 1995 .-$20 \mathrm{p}$.

16. Shernazarov E. New nesting birds of the Sundkli sand (south of Uzbekistan) // Uzbek Biological Journal, 1992, No. 1, S.58-61. 